Russell, C. \& Walker, T. K. (1953). J. gen. Microbiol. 8, 160-162.

\title{
Lactobacillus malefermentans n.sp., Isolated from Beer
}

\author{
By C. RUSSELL AND T. K. WALKER \\ College of Technology, University of Manchester
}

SUMMARY: A new species of heterofermentative Lactobacillus has been isolated from top-fermentation beer in which it occurs as a contaminant. The organism is distinguished principally by the fact that it ferments only glucose, maltose and inulin and, in consequence, it has been designated $L$. malefermentans.

During studies of lactic acid bacteria which infect brewery yeast and beer a rod-shaped organism which was isolated showed marked differences from other species of Lactobacillus described in the literature. Details of the isolation have already been published by Walker \& Parker (1943) and the organism was designated provisionally D2. A description of its characters and behaviour is now given.

\section{METHODS}

The behaviour of the organism was studied in liquid and in solid media prepared from beer, both hopped and unhopped, and from yeast-extract and peptone. Unlike many types of lactic acid bacteria which are found in beer the new organism was unable to proliferate in unhopped brewery wort. The action of the bacterium on carbohydrates was studied in a casein double digest prepared according to the directions of Davis (1939), and supplemented by addition of yeast autolysate $(1 \mathrm{ml} . / 100 \mathrm{ml}$. digest).

\section{DESCRIPTION OF THE ORGANISM}

\section{Morphological characters}

Shape, size and arrangement of cells. In unhopped beer after $24 \mathrm{hr}$. at $30^{\circ}$, the majority of the cells were $2-6 \mu$. long and all were rod-shaped. Single cells, pairs and a few short chains were noted. Motility was not observed.

Staining. The cells were Gram-positive. Neither endospores nor flagella were detected and attempts to detect capsules by the use of several staining procedures were unsuccessful.

\section{Cultural characters}

Growth on solid media, in $\mathrm{CO}_{2}$ at $25^{\circ}$. On a beer agar slope at 4 days, moderately strong growth, beaded to nodose; the colonies being greyish, glistening and mostly about 1-2 $\mathrm{mm}$. in diameter. On a yeast-extract peptone glucose (YEPG) agar slope at 7 days moderately strong nodose growth, the colonies being of irregular shape, white and opaque. On nutrient agar slope slight nodose growth.

Stab. In YEPG agar at $25^{\circ}$ for 5 days growth was strong and filiform and did not occur at the surface. In YEPG gelatin at room temperature during 5 days filiform growth developed without beading or branching. 
Growth in unhopped beer at $30^{\circ}$. A slight deposit was noted at 3 days, and on shaking the tube this produced a uniform billowy turbidity.

Growth in YEPG broth at $\mathbf{2 5 ^ { \circ }}$. At 2 days a moderate deposit had collected and gave a non-silky turbidity when shaken.

Growth in Lemco peptone broth in $\mathrm{CO}_{2}$ at $25^{\circ}$. At 6 days a scanty powdery sediment had collected and the liquid was clear.

\section{Physiological characters}

Relation to temperature: in unhopped beer the optimum range for growth is $25-34^{\circ}$ with a minimum temperature of $10^{\circ}$ and a maximum temperature of $37^{\circ}$. Relation to oxygen: facultative anaerobe. Relation to hydrogen-ion concentration: in unhopped beer the optimum $\mathrm{pH}$ value is 4.3 with limits $4 \cdot 1$ and 6.9 . Resistance to heat: killed by heating for $15 \mathrm{~min}$. at $60-65^{\circ}$ in unhopped beer. Resistance to hop antiseptic, markedly restricted.

\section{Biochemical characters}

Catalase reaction, negative. Formation of acetylmethylcarbinol, none. Nitrate reduction, none. Indole formation, none. Gelatin liquefaction, none. Action on litmus milk, no change.

Carbohydrates utilized. In a casein double digest medium supplemented with yeast autolysate the organism strongly attacked glucose, maltose and inulin, in all cases with production of acid, but no gas collected in Durham tubes. Dulcitol was attacked slightly. Inulin yielded more acid than did glucose. No other carbohydrates were effected by the organism.

Nature of the acid produced from glucose. Lactic acid was estimated by conversion to acetaldehyde after deproteinization of the medium with copper sulphate and calcium hydroxide and, after similar deproteinization of another sample of the medium, acetic acid was estimated after distillation in the presence of sulphuric acid. The molecular ratio of lactic acid to acetic acid in the medium was found to be $100: 38$. In a separate experiment the lactic acid was isolated as the zinc salt by the method of Pederson, Peterson \& Fred (1926) and was optically inactive.

\section{CLASSIFICATION}

The characters-a non-motile, non-sporing, Gram-positive rod, which is catalase-negative, facultatively anaerobic, does not reduce nitrate and ferments carbohydrates-places the organism in the tribe Lactobacilleae Winslow et al. of the family Lactobacteriaceae Orla-Jensen. The production of large amounts of lactic acid causes it to be assigned to the genus Lactobacillus Beijerinck. As to its specific characters the organism has been compared with species of Lactobacillus already described in the literature (Pederson, 1938; Orla-Jensen, 1942; Bergey's Manual, 1948; Shimwell, 1949). On the evidence it has been concluded that $L$. pastorianus van Laer is the only Lactobacillus species which shows in some respects attributes similar to D2. The latter usually is seen as rods about $2 \mu$. in length though forms up to $6 \mu$. in length may occur, whereas L. pastorianus is normally of length $5-10 \mu$. while filamentous forms up to 
$35 \mu$. in length have been noted. L. pastorianus shows beaded to arborescent growth in gelatin stabs, while D2 produces definitely a filiform growth in gelatin. Further, L. pastorianus produces acid in milk while D2 is unable to do so. Finally, L. pastorianus ferments arabinose, glucose, fructose, galactose, maltose and sucrose, while D2 can strongly attack only glucose, maltose and inulin, and exercise a weak action on dulcitol. Orla-Jensen (1942) has remarked that true lactic acid bacteria rarely attack dulcitol and then only slightly. It is also of interest to record that $\mathrm{D} 2$ attacks inulin even more vigorously than it attacks glucose, unexpected behaviour in view of the inability of this organism to assimilate fructose. These differences are deemed sufficiently large to justify species differentiation and, accordingly, we formally propose D2 as a new species under the designation $L$. malefermentans (male=peculiarly, fermentans = fermenting) which name has been chosen in view of the inability of the organism to ferment arabinose, xylose, fructose, galactose and sucrose and, on the other hand, of its markedly vigorous attack on inulin.

Lactobacillus malefermentans $\mathrm{n}$.sp. Rods $2-6 \mu$. in length, occurring principally as single cells and pairs. Non-motile, no endospores, Capsules and flagella not detected. Gram-positive. Colonies on beer agar beaded to nodose, greyish, glistening, 1-2 mm. diameter.

Facultative anaerobe. Optimum temperature $25-34^{\circ}$, minimum $10^{\circ}$, maximum $37^{\circ}$. Optimum $\mathrm{pH}$ value $4 \cdot 3$. Grows vigorously in unhopped beer and in yeast-extract peptone glucose broth. No growth in brewers' unhopped wort (a malt-extract solution). Attacks glucose, maltose and inulin with production of acid but not of gas. Dulcitol fermented weakly. Heterofermentative in glucose media, the lactic acid formed being optically inactive. Isolated at Manchester from sour beer, March 1942.

Subcultures from the type culture have been deposited at the National Collection of Industrial Bacteria, The Chemical Laboratory, Department of Scientific and Industrial Research, Teddington, Middlesex, (Culture No. NCIB 8517), at the National Institute for Research in Dairying, Shinfield, Reading, and at the Laboratories of the Brewing Industry Research Foundation, Nutfield, Surrey.

\section{REFERENCES}

Bergey's Manual of Determinative Bacteriology, 6th ed. (1948). Edited by BreEd, R. S., Murray, E. G. D. \& Hrtchens, A. P. London: Baillière, Tindall and Cox.

Davis, J. G. (1939). Practical hints on media in dairy bacteriology. Dairy Ind. 4, $331,360$.

Orla-Jensen, S. (1942). The Lactic Acid Bacteria, 2nd ed. Copenhagen: Ejnar Munksgaard.

Pederson, C. S. (1938). The gas-producing species of the genus Lactobacillus. J. Bact. 35, 95.

Pederson, C. S., Peterson, W. H. \& Fred, E. B. (1926). The forms of lactic acid produced by pure and mixed cultures of bacteria. J. biol. Chem. 68, 151.

Shimwell, J. L. (1949). The lactic acid bacteria (Family Lactobacteriaceae). Wallerstein Labs. Commun. 12, 71.

Walker, T. K. \& Parker, A. (1948). The isolation of lactic acid-producing bacteria from beer. J. Inst. Brew. 49, 280.

(Received 30 July 1952) 